\title{
EVOLUTION OF TECHNOLOGIES FOR CONSTRUCTION OF APARTMENT BUILDINGS - A TEMPORAL PERSPECTIVE
}

DOI: 10.18485/arh_pt.2020.7.ch32

\author{
_ Ivana Brkanić Mihić \\ Assistant professor, PhD, M.Arch, Josip Juraj Strossmayer University of Osijek, \\ Faculty of Civil Engineering and Architecture, Vladimira Preloga 3, 31000 Osijek, \\ Croatia, ibrkanic@gfos.hr
}

\author{
_ Matej Mihić \\ PhD, M.C.Eng, University of Zagreb, Faculty of Civil Engineering, \\ Kačićeva 26, 10000 Zagreb, Croatia, matej.mihic@grad.unizg.hr
}

\author{
_ Zvonko Sigmund \\ Assistant professor, PhD, M.C.Eng, University of Zagreb, Faculty of Civil \\ Engineering, Kačićeva 26, 10000 Zagreb, Croatia, zvonko.sigmund@grad.unizg.hr
}

\begin{abstract}
Designing apartment buildings is one of the most responsible tasks since it has the largest effect on the users and is their closest interaction with the built environment. People spend the most time in their homes and therefore it is imperative to explore all aspects of housing with the goal of understanding and subsequently improving the living conditions. Architectural research in housing is mostly focused on urban planning and on spatial characteristics of the apartments but there are other areas which need to be considered, such as the structural aspect.

The structural elements of the buildings are primarily important for the building stability, but also for the living comfort. Additionally, the choice of the structural elements influences both the building cost and the time needed for construction. Development of new materials and technologies has enabled faster and cheaper construction of apartment buildings of higher quality and has opened up new architectural design possibilities. The goal of this paper is to identify the time periods of predominant use of certain materials and structural systems in apartment buildings and to show the evolution of construction technologies through the prism of residential architecture. The sample used in this research consists of apartment buildings in Osijek, Croatia constructed from 1930 to 2015.
\end{abstract}

KEYWORDS _ apartment buildings, housing, construction

technologies, structural elements, residential architecture

\section{INTRODUCTION}

Housing is one of the most important components of social and economic development of a society, organization and arrangement of space and a big factor in raising the living standards of the population (MGIPU, 2013). Designing apartment buildings is one of the architects' most responsible tasks since it has the largest effect on the users and is their closest interaction with the built environment. People spend the most time in their homes and therefore it is imperative to explore all aspects of housing with the goal of understanding and subsequently improving the living conditions. Architec- 
tural research in housing is mainly focused on housing quality (HQl; Ren et al. 2018; Bennet et al, 2016), user satisfaction (Borgoni et al.2018; Milic \& Zhou, 2017), apartment characteristics (Tibesigwa et al, 2017; Mridha, 2015; Sima, 2015), apartment building characteristics (Nahtigal and Grum, 2015; Choi and Cho, 2014; Arce and Wyckmansa, 2014), and neighbourhood characteristics (Lea et al, 2016; Shin et al. 2016) which affect housing, as well as with social and economic (Streimikiene, 2015; Hadad et al, 2011) aspects of living. There are however, other areas which need to be considered, such as the structural aspect. The structural elements of the buildings are primarily important for the building stability, but also for the living comfort. Additionally, the choice of the structural elements influences both the building cost and the time needed for construction. Development of new materials and technologies has enabled faster and cheaper construction of apartment buildings of higher quality and has opened up new architectural design possibilities. In this paper, we will address the aspect of technologies and materials used in the construction of residential buildings in the City of Osijek built in the last 90 years.

City of Osijek is located in the eastern part of the Republic of Croatia with a population of about 80,000 and with more than 40,000 of housing units. In first half of the 20th century, it was a large industrial centre. Today, the city is in deep economic crisis that has triggered the emigration trend of its population. The history of residential housing in the city of Osijek can be traced back to the beginning of the 20th century when industrial companies started to build apartment buildings for their workers (Radović - Mahečić, D. 2006) but most of the Osijek apartment buildings were constructed in socialist time period, from 1945 to 1991 (Brkanić, I. and Atanacković - Jeličić, J., 2018).

The construction technologies that were used throughout the history in the city of Osijek were changing as the needs, possibilities and building policies of the times changed. Due to economic crisis and political decisions at the end of 1920s Osijek was left with a large number of empty homes which virtually stopped the construction industry. During 1930's fewer residential buildings were built (DAOS) but this situation changes after 1945 when the city gains an industrial as well as regional importance which boosted the construction industry. After the WW2, Osijek experienced the greatest socio-economic development triggered by the process of industrialization and urbanization and attracted people from the wider Slavonia and Baranja region. The whole socialist period is characterized by mass housing construction which sought to reduce the constant housing shortage since the population between 1948 and 1971 almost doubled. In the city of Osijek, more than 20 new residential areas were constructed between 1945 and 1991 (Brkanić et al., 2018). After a housing construction stagnation at the beginning of the 1990s private entrepreneurs started to build low-quality apartment buildings often situated in inappropriate locations (Bobovec et al., 2016).

The goal of this paper is to identify the time periods of predominant use of certain materials and structural systems in apartment buildings and to show the evolution of construction technologies through the prism of residential architecture. The sample used in this research consists of apartment buildings in Osijek, Croatia constructed from 1930 to 2015.

\section{METHODOLOGY}

After an extensive search of existing work which would describe the construction technologies in the observed time frame, and after consultations with colleagues who focus in the refurbishment of designated as cultural heritage, the Authors found that there does not exist a complete and comprehensive literature source which would present the evolution of construction technologies that appeared and were used in continental Croatia in the time frame of last 90 years.

Most of the research focuses on buildings constructed up to the first half of the 20th century. This is not surprising since these types of buildings are under some sort of protection as cultural heritage and their refurbishment requires special consideration, while the post-war architecture is relatively new and the original construction methods are not important in case of their refurbishment. Nevertheless, an overview of the development of new construction technologies, materials, and structural elements is important not just for encyclopaedic purposes, but as a base for further research, which 
intends to compare these developments with other socio-economic factors and to identify the connections and causal links.

To determine what construction technologies, materials, and structural elements appeared and when it was decided that the most effective way would be to study the design documentation of buildings constructed in that time period. Design documentation for buildings constructed up until 1991 was available at the city archives, while the documentation for more recent buildings was acquired through contacts with the designers and owners of those buildings. Design documentation consisted of various design drawings and descriptions of the building structure.

In parallel to acquiring design documents and before the analysis of the documentation, a database in the form of a table was created in which the data was to be entered. It was, of course, needed to define what characteristics are of interest to the research so that they can be read or inferred from the design documents.

The city of Osijek was chosen because its' buildings are representative of all the construction technologies in continental Croatia and the sample size is sufficient and yet manageable. Zagreb, as the national capital, has around eight times larger building stock, while other cities are much smaller than both Zagreb and Osijek, and the sample probably would not contain all building and technology types. Due to this research being a pilot study, the sample contained only 58 buildings. The idea was to fill the database with information from a representative sample to draw preliminary conclusions and to see whether some information regarding the buildings is missing and/or is not important for the research.

\section{STRUCTURAL CHARACTERISTICS OF THE OBSERVED RESIDENTIAL BUILDINGS}

Previous section introduced the database in which the data from design documents will be stored. The database was created in the form of an MS Excel table, in which the rows contain relevant data on each specific building, as defined in the columns of the table. The Authors chose which data to include in the table based on similar previous research and based on requirements of future planned research. Due to a large number of rows and columns in the database (60 and 38 respectively), it is not practical to be shown in the paper in its entirety, so it will be shown in excerpts and for a few buildings out of the total sample. An excerpt of the database, showing the first section with general information on buildings, is shown in Figure 1. The database is divided into 5 following sections, each of which will be described in detail in their respective subsections:

_ General information

_ Basement

_ Ground and upper floors

- Staircase

_ Roof structure

\begin{tabular}{|c|c|c|c|c|c|c|c|c|c|c|}
\hline $\begin{array}{c}\text { \# in the } \\
\text { database }\end{array}$ & Adress & $\begin{array}{c}\text { Street } \\
\text { number }\end{array}$ & $\begin{array}{c}\text { Begining of } \\
\text { construction }\end{array}$ & Stories & $\begin{array}{c}\text { Above } \\
\text { ground }\end{array}$ & $\begin{array}{c}\text { Under } \\
\text { ground }\end{array}$ & $\begin{array}{c}\text { Building } \\
\text { height }\end{array}$ & $\begin{array}{c}\text { Building } \\
\text { depth }\end{array}$ & $\begin{array}{c}\text { Length } \\
\text { on street } \\
\text { side }\end{array}$ & $\begin{array}{c}\text { Structural } \\
\text { dilations }\end{array}$ \\
\hline 6 & Vukovarska & 25 & 1936 & PO+PR+1 & 2 & 1 & 9,00 & 10,00 & 14,00 & No \\
\hline 17 & Vukovarska & $27 a$ & 1957 & PO+PR+3 & 4 & 1 & 12,30 & 9,60 & 13,00 & Yes \\
\hline 31 & Cvjetkova & 20 i 22 & 1970 & SU+PR+4 & 5 & 1 & 15,10 & 10,60 & 29,30 & No \\
\hline 45 & Sjenjak & $37,39,41$ & 1980 & PO+PR+12 & 13 & 1 & 39,00 & 18,81 & 43,82 & No \\
\hline 52 & Retfala Nova & $1,2,5,6$ & 2006 & Po+Pr+3 & 4 & 1 & 12,60 & 10,75 & 18,65 & No \\
\hline
\end{tabular}

_ Figure 1: Excerpt from the database (1/5) 


\section{General information}

This section of the database contains the basic information on the building, such as the address, the year in which the building started construction, how many stories it has above and below ground, outer dimensions, and whether the building is structurally dilated. This information is essential to be able to compare the structural elements based on the building's general characteristics and time when it was constructed.

\section{Basement}

The second section (presented in Figure 2) starts with the information on the structural systems. First two columns present the type and material of the foundations, followed by material and width of the basement walls and ceiling slabs. The final column contain information on the structural system of the basement.

\begin{tabular}{|c|c|c|c|c|c|c|}
\hline \multicolumn{7}{|c|}{ BASEMENT } \\
\hline $\begin{array}{c}\text { Foundation } \\
\text { type }\end{array}$ & $\begin{array}{c}\text { Foundatlon } \\
\text { materlal }\end{array}$ & $\begin{array}{c}\text { Materlal } \\
\text { of outer } \\
\text { basement } \\
\text { walls }\end{array}$ & $\begin{array}{l}\text { Width of } \\
\text { outer } \\
\text { basement } \\
\text { walls }\end{array}$ & $\begin{array}{l}\text { Materlal of } \\
\text { the celling } \\
\text { slab }\end{array}$ & $\begin{array}{l}\text { He lght of } \\
\text { the } \\
\text { celllng } \\
\text { slab }\end{array}$ & $\begin{array}{c}\text { Structural } \\
\text { system of the } \\
\text { basement }\end{array}$ \\
\hline $\begin{array}{c}\text { Strip } \\
\text { foundations }\end{array}$ & $\begin{array}{c}\text { Brick } \\
\text { masonny }\end{array}$ & $\begin{array}{c}\text { Brick } \\
\text { masoniry }\end{array}$ & 60 & $\begin{array}{c}\text { Wooden } \\
\text { beams }\end{array}$ & 0,4 & Longltudinal \\
\hline $\begin{array}{c}\text { Strip } \\
\text { foundations }\end{array}$ & Concrete & $\begin{array}{c}\text { Brick } \\
\text { masonry }\end{array}$ & 51 & $\begin{array}{c}\text { Seml- } \\
\text { prefab RC }\end{array}$ & 0,2 & Perpendicular \\
\hline $\begin{array}{c}\text { Strip } \\
\text { foundations }\end{array}$ & $\mathrm{RC}$ & Concrete & $\begin{array}{c}\text { Concrete } \\
\text { and RC }\end{array}$ & $\mathrm{RC}$ & 0,2 & RCframe \\
\hline $\begin{array}{c}\text { Foundation } \\
\text { slab }\end{array}$ & $R C$ & $\mathrm{RC}$ & 15 & $\mathrm{RC}$ & 0,2 & Perpendicular \\
\hline $\begin{array}{c}\text { Foundation } \\
\text { slab }\end{array}$ & $R C$ & RC & 20 & $\mathrm{AC}$ & 0,4 & Combined \\
\hline
\end{tabular}

_ Figure 2: Excerpt from the database (2/5)

\section{Ground floor and upper floors}

The third section of the database contains information on structural elements of ground floors. Materials and width of load-bearing walls, partition walls and ceiling slabs are presented. Additionally, the database contains information on whether the building has tie beams and tie columns, does the slab transfer loads in one or in two directions and the material of the topmost slab, if it differs from the slabs on lower levels. An excerpt of the database containing this information is shown in Figure 3.

\begin{tabular}{|c|c|c|c|c|c|c|c|c|c|c|c|}
\hline \multicolumn{12}{|c|}{ GROUND FLOOR AND UPPER FLOORS } \\
\hline $\begin{array}{c}\text { Material of } \\
\text { load bearing } \\
\text { walls }\end{array}$ & $\begin{array}{l}\text { Wall } \\
\text { width }\end{array}$ & $\begin{array}{l}\text { Structural } \\
\text { system of } \\
\text { upper floors }\end{array}$ & $\begin{array}{c}\text { Tie } \\
\text { beams }\end{array}$ & $\begin{array}{c}\text { Tie } \\
\text { column } \\
5\end{array}$ & $\begin{array}{c}\text { Material } \\
\text { of } \\
\text { partition } \\
\text { walls }\end{array}$ & $\begin{array}{c}\text { Partiton } \\
\text { wall } \\
\text { width }\end{array}$ & $\begin{array}{c}\text { Material of } \\
\text { the ceiling } \\
\text { slab }\end{array}$ & $\begin{array}{l}\text { Height of } \\
\text { the slab }\end{array}$ & $\begin{array}{c}\text { Span of } \\
\text { the ceiling } \\
\text { slab }\end{array}$ & $\begin{array}{l}\text { Load } \\
\text { bearing in } \\
\text { one or } \\
\text { two } \\
\text { directions }\end{array}$ & $\begin{array}{l}\text { Material of } \\
\text { the topmost } \\
\text { slab (if } \\
\text { different from } \\
\text { the rest) }\end{array}$ \\
\hline Brick masonry & 45 & Longitudinal & No & No & $\begin{array}{c}\text { Brick } \\
\text { masonry }\end{array}$ & 10 & $\begin{array}{c}\text { Wooden } \\
\text { beams }\end{array}$ & 0,45 & 4 and 4,5 & 1 & / \\
\hline Brick masonry & 25 & Perpendicular & Yes & No & $\begin{array}{c}\text { Brick } \\
\text { masonry }\end{array}$ & 7 & $\begin{array}{c}\text { Semi- } \\
\text { prefab } R C\end{array}$ & 0,27 & 4 & 1 & / \\
\hline $\begin{array}{l}\text { Brick masonry } \\
\text { and concrete }\end{array}$ & 20 & $\begin{array}{l}\text { RCframe with } \\
\text { bracing walls }\end{array}$ & No & No & $\begin{array}{c}\text { Brick } \\
\text { masonry }\end{array}$ & 7 & $\mathrm{RC}$ & 0,2 & $2,8 \times 4,6$ & 2 & / \\
\hline $\mathrm{RC}$ & 15 & Perpendicular & No & No & $\begin{array}{c}\text { Brick } \\
\text { masonry }\end{array}$ & 7 and 12 & $\mathrm{RC}$ & 0,16 & 3,6 & 1 & / \\
\hline$R C$ & 20 & Combined & No & No & $\begin{array}{l}\text { Drywall } \\
\text { panels }\end{array}$ & 8 & $R C$ & 0,29 & $\begin{array}{c}3,2 \text { up to } \\
8,85\end{array}$ & 1 and 2 & / \\
\hline
\end{tabular}




\section{STAIRCASE AND ROOF STRUCTURE}

The final two sections show the information on the buildings' roof structures and staircases. For the roof structures it is important to know the type of the roof, structural type, material and slant, while for the staircases information on structural type, materials, number of flights and anchoring methods are of importance to this paper. Due to a relatively small number of information required, sections 4 and 5 are presented together in Figure 4.

\begin{tabular}{|c|c|c|c|c|c|c|c|}
\hline \multicolumn{4}{|c|}{ STAIRCASE } & \multicolumn{4}{|c|}{ ROOF STRUCTURE } \\
\hline Structural type & Material & $\begin{array}{l}\text { Number } \\
\text { of flights }\end{array}$ & $\begin{array}{c}\text { Method of } \\
\text { anchoring the } \\
\text { landing }\end{array}$ & Type & $\begin{array}{l}\text { structura } \\
\text { type }\end{array}$ & Material & Slant \\
\hline $\begin{array}{c}\text { RC stairs on } \\
\text { steel tend ons }\end{array}$ & $R C$ & 2 & $\begin{array}{c}\text { RC slab on } \\
\text { steel ten dons }\end{array}$ & \begin{tabular}{|c|} 
Double queen \\
post
\end{tabular} & Queen post & Wood & $\begin{array}{c}\text { Multipitched } \\
\text { roof }\end{array}$ \\
\hline cantilevered & $R C$ & 2 & RCsab & $\begin{array}{c}\text { Double queen } \\
\text { post }\end{array}$ & Queen post & wood & $\begin{array}{c}\text { Double pitched } \\
\text { roof }\end{array}$ \\
\hline $\begin{array}{c}\text { RC stairs on } \\
\text { tend ons }\end{array}$ & $\begin{array}{c}\text { Prefabricated } \\
\text { RC } \\
\end{array}$ & 2 & RCsab & Flat roof & Classical & $R C$ & Fiat roof \\
\hline RCslab & $\begin{array}{c}\text { Prefabricated } \\
\text { RC }\end{array}$ & 2 & RCalab & Fiat roof & Reversed & $R C$ & Fiat roof \\
\hline $\begin{array}{l}\text { FClgure 4. EXo } \\
\text { RC }\end{array}$ & $\begin{array}{c}\text { erpts Trom th } \\
\text { RC }\end{array}$ & 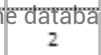 & $\begin{array}{c}\text { Se }(4 / 5) \text { alnd } \\
\text { RCsab }\end{array}$ & $\begin{array}{r}(5 / 5) \\
\text { Flat roof }\end{array}$ & Reversed & $R C$ & Fiat roof \\
\hline
\end{tabular}

\section{DISCUSSION}

After all the data for the buildings in the sample were entered in the database, the following step was the primary goal of the research, to see and compare how did the construction technology and materials change through time. For easier manipulation with the data and because of already suspected differences between the construction technologies, the buildings in the sample were divided into 5 groups based on the predominant housing policies during that time (Tsenkova, S. 2009; Brkanić et al. 2018). Those 5 groups are:

1. before $1945-9$ buildings in the sample (Pre-socialist Period)

2. 1945-1959 - 11 buildings in the sample (Socialist Period - a period of establishment of the socialist housing system)

3. 1960-1975 - 17 buildings in the sample (Socialist Period - a period of revolutionary reforms)

4 1976-1991 - 13 buildings in the sample (Socialist Period - a period of marketization)

5. after $1991-8$ buildings in the sample (Post-Socialist Period)

To textually compare all building characteristics of different time periods would be the most detailed method. However, it might be more difficult for the reader to interconnect all the information and it would take too much space in the paper. Table format, on the other hand, would be most suitable to succinctly show the developments, but it has its own limitations. When presenting data in a table format, some nuances may be lost, and correlations cannot be explicitly stated. Therefore, the most significant consequence of construction technology development is described in most detail in the next subsection, while other characteristics will be presented in the table below.

\section{Comparison of advances in technology related to building height}

When comparing the buildings' general characteristics, the most significant fluctuation throughout the time period is building height. In the first time period, the buildings are relatively low, with only two or three stories aboveground. In the second period, we can see that the average height rises to around four to six stories. There are two likely reasons for this scenario. The first is the larger need for housing in the urban centre and the other is the development of new construction materials and 
technologies. During the second time period, concrete foundations phased out the masonry foundations and prefabricated reinforced concrete (RC) slabs replaced wooden beams, among others. The third time period further accentuates the growth in height with many residential buildings with 10 or more stories being built. This is also because a large number of people moved to the urban centres, but still, it would not be possible to house them in such buildings without further improvement in construction technologies. Most notable improvements include the increased use of reinforced concrete for the load-bearing elements, primarily slabs, walls, beams and columns. Additionally, the appearance of new structural elements and systems such as RC frame structures and foundation piles, and using RC instead of brick masonry for load-bearing walls have enabled higher buildings to be built. This, of course, does not mean that it was impossible to build higher buildings before, but that these advancements made higher structures more affordable to build.

Buildings in the fourth time period remain for the most part the same height, but in the last time period, even though more and more structural developments become evident, the height of the constructed buildings is at most 6 stories. This may be due to zoning regulations, due to decreased influx of people to the urban areas, but also due to the fact that higher structures are more expensive to construct per square meter and developers (which are now private, not mostly public) have no financial incentives to construct higher buildings. From that rather simple example of how one building characteristic had changed through time, we can see not just how the need and development of technologies influence each other, but also how many outside factors influence how and why residential buildings are constructed. Therefore, it is of relative importance to have a comprehensive overview of how construction technologies have changed over time and what has influenced the change.

\section{Comparison of most frequent structural elements for each of the time periods}

As it was mentioned earlier in the paper, to enable easier comparison of the structural elements prevalent in each of the time periods, the data was structured in a table form. Due to constraints of the table, only the most distinct materials, elements, sizes, etc. could be shown. An additional disadvantage is that new developments and unique occurrences cannot be shown in the table itself. Therefore, this section will provide not only the commentary of the data presented in Table 1, but also all the data that could not be shown in the table.

Some general conclusions from the data in the table can be gathered. First and foremost, the height of the buildings has risen dramatically due to rising demand but facilitated by the improvements in construction technology. Foundation type changed from strip foundations to piles for higher structures and to foundation slabs for newer buildings. Strip foundations were made from brick masonry and were gradually phased out first by concrete and then concrete by reinforced concrete (RC).

A similar situation happened with the basement walls and also with all load-bearing walls in general. They gradually transformed from masonry, through concrete to RC. Their width also reduced with new materials being introduced and with more detailed structural analysis available. Basement walls have reduced their initial width from $60 \mathrm{~cm}$ for masonry walls to $20 \mathrm{~cm}$ for RC walls and load-bearing walls from $45 \mathrm{~cm}$ to around $20 \mathrm{~cm}$. Partition walls have also reduced their width from $15 \mathrm{~cm}$ in the first period to $7 \mathrm{~cm}$ in the fourth period. Curiously, the width increased in the last period, most likely because of sound insulation. As for materials, a vast majority is made of brick masonry but however, the third period features aerated concrete blocks and fifth period drywall panels.

_ Table 1. Comparison of prevalent structural elements throughout the observed time periods

\begin{tabular}{lllllll}
\hline & $\begin{array}{l}\text { Building element } \\
\text { or characteristic }\end{array}$ & Before 1945 & 1945 to 1959 & 1960 to 1975 & 1976 to 1991 & After 1991 \\
\hline \hline & $\begin{array}{l}\text { Building height } \\
\text { (number of } \\
\text { aboveground } \\
\text { stories) }\end{array}$ & 2 or 3 & 4 or 5 & $\begin{array}{l}\text { Mostly } 5 \text { or 6, with } \\
10 \text { to } 12 \text { also } \\
\text { present }\end{array}$ & $\begin{array}{l}\text { Mostly } 5 \text { or 6, } \\
\text { with 10 to } 12 \\
\text { also present }\end{array}$ & 4 or 5 \\
\cline { 2 - 7 } & $\begin{array}{l}\text { Underground } \\
\text { stories }\end{array}$ & 1 & 1 & 1 & 1 & 1 , some 0 \\
\cline { 2 - 7 } & Structural dilations & None & $\begin{array}{l}\text { Seldom } \\
\text { occurring }\end{array}$ & Seldom occurring & $\begin{array}{l}\text { Seldom } \\
\text { occurring }\end{array}$ & $\begin{array}{l}\text { Seldom } \\
\text { occurring }\end{array}$ \\
\hline
\end{tabular}




\begin{tabular}{|c|c|c|c|c|c|c|}
\hline \multirow{4}{*}{ 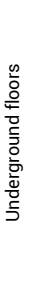 } & $\begin{array}{l}\text { Foundation } \\
\text { type/material }\end{array}$ & $\begin{array}{l}\text { Strip } \\
\text { foundations; } \\
\text { brick masonry }\end{array}$ & $\begin{array}{l}\text { Strip } \\
\text { foundations; } \\
\text { Concrete }\end{array}$ & $\begin{array}{l}\text { Strip foundations; } \\
\text { Concrete and RC }\end{array}$ & $\begin{array}{l}\text { Strip } \\
\text { foundations; } \\
\text { Concrete and RC }\end{array}$ & $\begin{array}{l}\text { Strip } \\
\text { foundations and } \\
\text { foundation } \\
\text { slabs; RC }\end{array}$ \\
\hline & Structural system & Longitudinal & $\begin{array}{l}\text { Longitudinal } \\
\text { and } \\
\text { perpendicular }\end{array}$ & $\begin{array}{l}\text { Longitudinal and } \\
\text { perpendicular }\end{array}$ & Perpendicular & Combined \\
\hline & $\begin{array}{l}\text { Basement wall } \\
\text { type/ material / } \\
\text { width }\end{array}$ & $\begin{array}{l}\text { Brick } \\
\text { masonry; } 51 \\
\text { or } 60 \mathrm{~cm}\end{array}$ & $\begin{array}{l}\text { Masonry; } 38 \text { and } \\
51 \mathrm{~cm}\end{array}$ & $\begin{array}{l}\text { Concrete and } \\
\text { brick masonry; } 25 \\
\mathrm{~cm}\end{array}$ & $\mathrm{RC}, 20 \mathrm{~cm}$ & $\mathrm{RC} ; 20$ to $25 \mathrm{~cm}$ \\
\hline & $\begin{array}{l}\text { Basement ceiling } \\
\text { slab type / } \\
\text { material / height }\end{array}$ & $\begin{array}{l}\text { Semi- } \\
\text { prefabricated } \\
\mathrm{RC} ; 40 \mathrm{~cm}\end{array}$ & $\begin{array}{l}\text { Semi- } \\
\text { prefabricated } \\
\text { RC; } 20 \text { to } 40 \mathrm{~cm}\end{array}$ & $\begin{array}{l}\text { Monolithic RC; } 30 \\
\mathrm{~cm}\end{array}$ & $\begin{array}{l}\text { Semi- } \\
\text { prefabricated } \\
\mathrm{RC} ; 20 \mathrm{~cm}\end{array}$ & $\begin{array}{l}\text { Monolithic RC; } \\
20 \mathrm{~cm}\end{array}$ \\
\hline \multirow{7}{*}{ 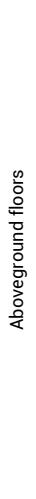 } & Structural system & Longitudinal & $\begin{array}{l}\text { Longitudinal } \\
\text { and } \\
\text { perpendicular }\end{array}$ & $\begin{array}{l}\text { Longitudinal and } \\
\text { perpendicular }\end{array}$ & Perpendicular & Combined \\
\hline & $\begin{array}{l}\text { Load bearing walls } \\
\text { material / width }\end{array}$ & $\begin{array}{l}\text { Brick } \\
\text { masonry; } 45 \\
\mathrm{~cm}\end{array}$ & $\begin{array}{l}\text { Brick masonry; } \\
25 \text { and } 38 \mathrm{~cm}\end{array}$ & $\begin{array}{l}\mathrm{RC} \text { and brick } \\
\text { masonry; } 25 \mathrm{~cm}\end{array}$ & $\begin{array}{l}\mathrm{RC} \text { and brick } \\
\text { masonry; } 20 \mathrm{~cm}\end{array}$ & $\begin{array}{l}\mathrm{RC} \text { and brick } \\
\text { masonry; } 20 \text { to } \\
30 \mathrm{~cm}\end{array}$ \\
\hline & $\begin{array}{l}\text { Tie beams and tie } \\
\text { columns }\end{array}$ & None & Tie beams only & Both & Both & Both \\
\hline & $\begin{array}{l}\text { Partition wall } \\
\text { material / width }\end{array}$ & $\begin{array}{l}\text { Brick } \\
\text { masonry; } 10 \\
\text { or } 15 \mathrm{~cm}\end{array}$ & $\begin{array}{l}\text { Brick masonry; } \\
10 \mathrm{~cm}\end{array}$ & $\begin{array}{l}\text { Brick masonry and } \\
\text { siporex; } 7 \mathrm{~cm}\end{array}$ & $\begin{array}{l}\text { Brick masonry; } \\
7 \mathrm{~cm}\end{array}$ & $\begin{array}{l}\text { Brick masonry } \\
\text { and drywall } \\
\text { panels; } 12 \mathrm{~cm}\end{array}$ \\
\hline & $\begin{array}{l}\text { Ceiling slab type / } \\
\text { material / height }\end{array}$ & $\begin{array}{l}\text { Wooden } \\
\text { beams; } 45 \mathrm{~cm}\end{array}$ & $\begin{array}{l}\text { Semi- } \\
\text { prefabricated } \\
\text { RC; } 20 \text { to } 40 \mathrm{~cm}\end{array}$ & $\begin{array}{l}\text { Monolithic RC; } 20 \\
\mathrm{~cm}\end{array}$ & $\begin{array}{l}\text { Semi- } \\
\text { prefabricated } \\
\mathrm{RC} ; 25 \mathrm{~cm}\end{array}$ & $\begin{array}{l}\text { Semi- } \\
\text { prefabricated } \\
\text { and monolithic } \\
\mathrm{RC} ; 30 \mathrm{~cm}\end{array}$ \\
\hline & $\begin{array}{l}\text { Span and load } \\
\text { distribution type }\end{array}$ & $\begin{array}{l}4 \text { to } 5 \mathrm{~m} \text {; load } \\
\text { transfer in } 1 \\
\text { direction }\end{array}$ & $\begin{array}{l}4 \text { to } 5 \mathrm{~m} \text {; load } \\
\text { transfer in } 1 \\
\text { direction }\end{array}$ & $\begin{array}{l}3 \text { to } 4 \mathrm{~m} \text {; load } \\
\text { transfer in } 1 \text { and } 2 \\
\text { directions }\end{array}$ & $\begin{array}{l}4 \mathrm{~m} \text {; load } \\
\text { transfer in } 1 \text { and } \\
2 \text { directions }\end{array}$ & $\begin{array}{l}4 \text { to } 7 \mathrm{~m} \text {; load } \\
\text { transfer in } 1 \text { and } \\
2 \text { directions }\end{array}$ \\
\hline & $\begin{array}{l}\text { Topmost slab } \\
\text { different from the } \\
\text { rest? }\end{array}$ & Sometimes & No & No & No & No \\
\hline \multirow{4}{*}{ 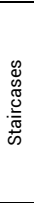 } & Structural type & $\begin{array}{l}\text { RC stairs on } \\
\text { steel tendons }\end{array}$ & Cantilevered & $\begin{array}{l}\text { RC stairs on } \\
\text { tendons }\end{array}$ & RC slab & RC slab \\
\hline & Material & $\mathrm{RC}$ & RC slab & $\begin{array}{l}\mathrm{RC} \text { and } \\
\text { prefabricated } \mathrm{RC}\end{array}$ & $\begin{array}{l}\mathrm{RC} \text { and } \\
\text { prefabricated } \\
\mathrm{RC}\end{array}$ & $\mathrm{RC}$ \\
\hline & Nubmer of flights & 2 & 2 & 2 & 1 and 2 & 2 \\
\hline & $\begin{array}{l}\text { Method of } \\
\text { anchoring the } \\
\text { landing }\end{array}$ & $\begin{array}{l}\text { RC slab on } \\
\text { steel tendons }\end{array}$ & $\mathrm{RC}$ slab & $\mathrm{RC}$ slab & $\begin{array}{l}\text { RC beam and } \\
\text { slab }\end{array}$ & $\mathrm{RC}$ slab \\
\hline \multirow{3}{*}{ tᄒ } & Structural type & $\begin{array}{l}\text { Double queen } \\
\text { post }\end{array}$ & $\begin{array}{l}\text { Double queen } \\
\text { post and } \\
\text { raftered }\end{array}$ & Flat roof & Raftered & Flat and rafted \\
\hline & Material & Wood & Wood & $\mathrm{RC}$ & Wood and RC & $\mathrm{RC}$ \\
\hline & Slant & $\begin{array}{l}\text { Double piched } \\
\text { and multi- } \\
\text { pitched }\end{array}$ & $\begin{array}{l}\text { Double pitched } \\
\text { and flat roof }\end{array}$ & Flat roof & $\begin{array}{l}\text { Flat and double } \\
\text { pitched roof }\end{array}$ & $\begin{array}{l}\text { Flat and double } \\
\text { pitched roof }\end{array}$ \\
\hline
\end{tabular}

In the first two periods, the structural system contained only load-bearing walls and slabs (parallel to the street façade, perpendicular to it, or a combination of the two). The following periods also have load-bearing walls as prevalent structural systems, but however first RC frame appeared in 1963. The first tie beam appeared in 1953 and tie column in 1966. It could be interesting to see whether their first appearance and subsequent use relates to perhaps new seismic regulations.

Ceiling slabs have also seen similar improvement over the years. Only the first period features wooden beams, while the following periods predominantly use either semi-prefabricated RC systems or monolithic cast in place RC slabs. Their average height has also reduced from $40 \mathrm{~cm}$ in the $1940 \mathrm{~s}$ to $20 \mathrm{~cm}$ in the third period. From the table we can see that the height increased in fourth and fifth periods. This can be explained by an increased span of the slabs and increased prevalence of semi-prefabricated slabs in favour of cast in place slabs, later of which can be more expensive and take more time to build. In most cases, slabs transfer loads in only one direction. This is expected because of the structural system and because larger spans are rarely needed in residential construction. Prestressed concrete slabs are also quite rare, appearing in only three buildings in the sample as a type of a semi-prefabricated slab.

Structural systems of stairways are quite different to each other, not just through the time periods, but within the periods themselves. It would be necessary to study a larger sample to see whether one type would stand out as the most frequent. Some conclusions can, however, be drawn, such as that $\mathrm{RC}$ is the overwhelmingly most common material. The first period has predominant RC stairs and landings on steel tendons, the second period has cantilevered RC stairs and landings. Prefabri- 
cated stairways first appear in the second time period and become most widespread in the third and fourth periods. In the last period, monolithic RC slabs become the norm.

Roof structures have also seen improvements through the observed periods. The first period features exclusively wooden traditional structures and double and multi-pitched roofs. Prefabricated $\mathrm{RC}$ roof slabs begin appearing in the second period and in the third period all but one roofs are flat roofs with either monolithic or prefabricated RC slabs. The fourth period features the reappearance of wooden roof structures, modernised in structural design to use less material per roof area. The last period is similar to the third, with mostly prefabricated and monolithic RC slabs. Some roofs, however, are slanted and one of them has a steel truss for the roof's bearing structure.

\section{CONCLUSION}

The goal of the paper was to present the evolution of construction technologies of apartment buildings. Through the review of previous research, the Authors concluded that no similar research had studied and comprehensively presented construction technologies of buildings built from the 1930s until today. This paper presented the most common structural elements, types and materials as well as other structural characteristics of buildings constructed in Osijek from 1930 to 2015 . While the sample was chosen due to the availability of design documents in city archives and the overall city size, the Authors consider that it is representative of construction technologies in continental Croatia and even across borders in countries with similar socioeconomic backgrounds.

This research has successfully identified the evolution of construction technologies through time. The results were collected in a database and presented in the table format, accompanied by textual clarifications. It was expected that most of the changes in the building stock would be connected to housing policies, therefore for better readability and manageability of the data, the buildings were divided into five time periods based on the predominant housing policies during that time.

Table 1 in the previous section contains information most common structural element types, materials, dimensions, etc. for each of the periods and the change in structural elements and evolution of construction technologies can clearly be seen. These results can serve not just as encyclopaedic knowledge but also as a starting point for more focused research into how and why have the construction technologies evolved through time.

However, after analysing the buildings in the sample, it became evident that additional information could be included in the database and that the sample size is too small for drawing conclusions with a high degree of certainty. Therefore, the study should be repeated with a larger sample and with, for example, information on building façades. Future research should also study the connections of changes in prevalent construction types and materials with new technological advancements, regulatory requirements and socioeconomic aspects, to name a few.

\section{REFERENCES}

- Acre, F. and Wyckmansa, A. 2014. "Spatial quality determinants for residential building renovation: A methodological approach to the development of spatial quality assessment." International Journal of Sustainable Building Technology and Urban Development, 5, no 3: 183-204.

- Bennett, J. et al. 2016. "Towards an agreed quality standard for rental housing: Field testing of a New Zealand housing WOF tool." Australian and New Zealand Journal of Public Health: 1-7, https://doi. org/10.1111/1753-6405.12519

- Bobovec, Borka, Mlinar, Ivan and Pozojevic, Andriana. 2016. "Housing Construction Programs in Croatia between 1991 and 2016." Prostor 24, no. 2: 216-227.

- Borgoni, Riccardo, Michelangeli, Alessandra \& Pirola, Federica. 2018. "Residential Satisfaction for a Continuum of Households: Evidence from European Countries." SSRN Electronic Journal. 10.2139/ 
ssrn.3151414

_ Brkanić, Ivana, Stober Dina and Mihić, Matej. 2018. "A Comparative Analysis of the Spatial Configuration of Apartments Built in Osijek, Croatia, between 1930 and 2015." Journal of Asian Architecture and Building Engineering 17, no. 1: 23-30.

_ Brkanić, Ivana and Atanacković - Jeličić, Jelena. 2018. "Socialist housing in Osijek." Electronic Journal of the Faculty of Civil Engineering Osijek-e-GFOS 17: 1-10.

_ Choi, J. and Cho, T. 2014. "Comparing perception concerning the importance of apartment complex components between consumers and housing providers." Journal of Asian Architecture and Building Engineering, 13, no. 1: 109-116.

_ DAOS, Fond gradsko poglavarstvo Osijek (1848. - 1945.). "Zapisnici glavnih skupština gradskog zastupstva, HR-DAOS-0010, knj. 1084/ 1933."

_ Haddad, M.; Judeh, M. and Haddad, S. 2011. „Factors affecting buying behavior of an apartment: An empirical investigation in Amman, Jordan." Research Journal of Applied Sciences, Engineering and Technology, 3, no. 3: 234-239.

_ Housing Quality Indicators HQI. Accessed February 92020 https://www.gov.uk/guidance/housing-quality-indicators\#hqi-calculator.

_ Lea, L.H.; Ta, A.D. and Dang, H.Q. 2016. „Building up a system of indicators to measure social housing quality in Vietnam" Procedia Engineering, 142: 115-122.

_ MGIPU. 2013. "Izvješće o stanju u prostoru Republike Hrvatske 2008. - 2012." Accesed April 5, 2020 https://mgipu.gov.hr/UserDocsImages/Zavod/Publikacije/Izvjesce_SPRH_08_12.pdf.

_ Milic, Jelena and Zhou, Jingmin. 2017. "Residential satisfaction among young people in post-socialist countries: the case of Serbia." Journal of Housing and the Built Environment: 1-16. 10.1007/s10901017-9579-9.

_ Mridha, M. 2015. "Living in an apartment." Journal of Environmental Psychology, 43: 42-54.

- Nahtigal, D and Grum, B. 2015. "Segmentation and the Value frame of buyers of residential apartments." Geodetski vestnik, 59 no. 1: 71-101.

_ Radović-Mahečić, Darja. 2006. "Osječka arhitektura između dva svjetska rata u kontekstu hrvatske moderne arhitekture." In Osječka arhitektura: 1918.-1945, edited by Martinčić, J., and Hackenberger D., 21.34. Osijek: Hrvatska akademija znanosti i umjetnosti i Zavod za znanstveni i umjetnički rad u Osijeku. _ Ren, Honghao, Yuan, Nannan and Hu, Huimin. 2018. "Housing quality and its determinants in rural China: a structural equation model analysis." Journal of Housing and the Built Environment. 34. 10.1007/ s10901-018-9629-y.

_ Sima, L. 2015. "Study on small apartment design in China: Evaluation on the impressions of and preferences for the floor plans-" Journal of Asian Architecture and Building Engineering, 14 no. 2: 307-314.

- Shin, E.K.; Hong, S. and Kim, S. 2016. "Changes in public perception of apartments: Television and newspaper advertisements, 1960-2010." Journal of Asian Architecture and Building Engineering, 15 no. 1: 65-72.

- Streimikiene, D. 2015. "Quality of life and housing, International Journal of Information and Education Technology." 5, no. 2: 140-145

- Tibesigwa, B.M.; Hao, L.; Karumuna, B.V. 2017. "The concept of spatial quality and its challenges on exercised affordable housing design typology in Dar es Salaam - Tanzania," Habitat International, 59: 44-59

- Tsenkova, Sasha. 2009. Housing Policy Reforms in Post Socialist Europe: Contribution to Economics. Heidelberg: Physica-Verlag. 